Syntax Literate: Jurnal Ilmiah Indonesia p-ISSN: 2541-0849 e-ISSN: 2548-1398

Vol. 6, No. 2, Februari 2021

\title{
ANALISIS PEMERIKSAAN PAJAK DENGAN MODEL COMPLIANCE RISK MANAGEMENT (CRM) DALAM MENINGKATKAN PENERIMAAN PAJAK PADA KPP PRATAMA SENEN
}

\section{Tri Puji Astuti dan Gunadi}

Fakultas Ilmu Administrasi, Universitas Indonesia

Email: asthy.asti@gmail.com dan triguna.gunadi@gmail.com

\begin{abstract}
The Directorate General of Taxes in order to increase tax revenue issued a regulation, namely SE-24 / PJ / 2019 regarding the Implementation of Compliance Risk Management (CRM), one of which regulates tax supervision and audit activities. Compliance Risk Management is a Taxpayer compliance risk management process that is carried out systematically by the Directorate General of Taxes by making treatment choices that can be used to increase compliance effectively while preventing non-compliance based on the behavior of the Taxpayer and the capacity of its resources. This study aims to analyze the implementation and evaluation of tax audits with Compliance Risk Management in increasing tax revenue at KPP Pratama Senen. The research method used is a descriptive qualitative approach with literature study and in-depth interviews. The results showed that the tax audit with Compliance Risk Management resulted in the achievement of tax revenue at KPP Pratama Senen amounting to 1,599,611,317,526 or an achievement of 118.50\% and an increase in individual taxpayer compliance to $101 \%$ and corporate taxpayers to $83 \%$. and evaluation of the implementation of Compliance Risk Management using six indicators according to William Dunn, namely: effectiveness, efficiency, leveling, adequacy, responsiveness, and accuracy.
\end{abstract}

Keywords: Compliance Risk Management, Supervision and Audit Tax

\begin{abstract}
Direktorat Jenderal Pajak dalam rangka meningkatkan penerimaan pajak mengeluarkan aturan yaitu SE-24/PJ/2019 mengenai Implementasi Compliance Risk Management (CRM), dimana salah satu nya mengatur mengenai kegiatan pengawasan dan pemeriksaan pajak. Compliance Risk Management merupakan sebuah proses pengelolaan risiko kepatuhan Wajib Pajak yang dilakukan secara sistematis oleh Direktorat Jenderal Pajak dengan membuat pilihan perlakuan yang dapat digunakan untuk meningkatkan kepatuhan secara efektif sekaligus mencegah ketidakpatuhan berdasarkan perilaku Wajib Pajak dan kapasitas sumber daya yang dimiliki. Penelitian ini bertujuan untuk menganalisis penerapan dan evaluasi pemeriksaan pajak dengan Compliance Risk Management dalam meningkatkan penerimaan pajak pada KPP Pratama Senen. Metode penelitian yang digunakan adalah pendekatan kualitatif deskriptif dengan studi kepustakaan dan wawancara mendalam. Hasil penelitian menunjukkan pemeriksaan pajak dengan Compliance Risk Management itu menghasilkan pada tahun 2020 tercapainya penerimaan pajak
\end{abstract}


pada KPP Pratama Senen sebesar 1.599.611.317.526 atau capaian 118,50\% dan meningkatnya kepatuhan wajib pajak orang pribadi menjadi $101 \%$ dan wajib pajak badan menjadi $83 \%$. dan evaluasi penerapan Compliance Risk Management dengan menggunakan enam indikator menurut William Dunn yaitu : efektivitas, efisiensi, perataan, kecukupan, responsivitas, dan ketepatan.

Kata Kunci: Compliance Risk Management, Pengawasan dan Pemeriksaan Pajak.

\section{Coresponden Author}

Email: asthy.asti@gmail.com Artikel dengan akses terbuka dibawah lisensi

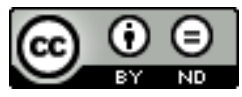

\section{Pendahuluan}

Tantangan utama yang dihadapi pemerintah dan otoritas pajak adalah ketidakpatuhan terhadap peraturan dan regulasi perpajakan (OECD, 2001). Kepatuhan selalu, dan hampir pasti akan selalu, menjadi, masalah utama dalam administrasi perpajakan (Mason, 2008). Menurut (Leviner, 2008), penelitian telah membuktikan bahwa "ketidakpatuhan pajak adalah masalah yang serius dan kompleks, tergantung pada berbagai penyebab". Ketidakpatuhan pajak juga merupakan masalah universal yang dihadapi oleh setiap negara dalam menyelenggarakan kebijakan pajak.

Ketidakpatuhan pajak merupakan salah satu risiko yang harus dikelola oleh administrasi perpajakan untuk memenuhi tujuannya dalam mengumpulkan penerimaan untuk pembangunan negara. Sejalan dengan sudut pandang yang dikemukakan oleh peneliti, otoritas pajak juga mengakui fakta bahwa tidak semua wajib pajak bersedia melaporkan penghasilannya dan membayar pajak. Faktanya, penelitian telah membuktikan bahwa ada wajib pajak yang bersedia melakukan apa saja untuk menghindari kepatuhan terhadap undang-undang perpajakan (Braithwaite et al, 2005; Ayres dan Braithwaite, 1992; Kirchler et al., 2003). Dengan memahami kepatuhan pajak, akan mudah bagi otoritas pajak untuk menemukan cara untuk mengatasi masalah ini dan merencanakan strategi untuk mengelolanya.

Ketidakpatuhan pajak dapat dibedakan menjadi penghindaran pajak (tax avoidance) dan penggelapan pajak (tax evasion). Kedua aktivitas ini berbeda dari segi legalitasnya. Penghindaran pajak merupakan usaha mengurangi kewajiban pajak dengan menggunakan aturan pajak yang ada, sedangkan penggelapan pajak merupakan pelanggaran terhadap aturan pajak. Untuk mengurangi perilaku penghindaran pajak, pembuat kebijakan dapat menggunakan hukum dengan menjadikan modus penghindaran pajak sebagai suatu yang ilegal sehingga upaya penegakan hukum (legal enforcement) dapat digunakan (Blaufus Et al., 2016).

(Nurmantu (2005)) menyatakan bahwa kepatuhan Wajib Pajak dapat didefinisikan sebagai suatu keadaan dimana Wajib Pajak memenuhi semua kewajiban perpajakan dan melaksanakan hak perpajakannya. Nurmantu kemudian membedakan kepatuhan tersebut menjadi dua yaitu kepatuhan formal dan kepatuhan material. Kepatuhan formal adalah 
suatu keadaan dimana Wajib Pajak memenuhi kewajiban perpajakan secara formal sesuai dengan ketentuan dalam Undang-Undang Perpajakan. Di sisi lain, kepatuhan material adalah suatu keadaan dimana Wajib Pajak secara substanstif memenuhi serangkaian ketentuan material perpajakan sesuai dengan isi dan jiwa Undang-Undang Perpajakan.

Upaya meningkatkan kepatuhan (tax compliance) pada wajib pajak berkaitan erat dengan pelaksanaan fungsi pemeriksaan. Keterbukaan dan kejujuran dari wajib pajak dalam melaporkan pajak terutang memberikan kemudahan bagi petugas pemeriksa pajak dalam melakukan pemeriksaaan. Namun, jumlah wajib pajak jauh lebih banyak dibandingkan dengan petugas pemeriksaan pajak, maka mustahil pemeriksaan dilakukan terhadap seluruh wajib pajak. Menurut (Birskyte, 2008), dengan terungkapnya kasus penggelapan pajak dari wajib pajak dapat meningkatkan penerimaan negara, dan pemeriksaan itu bisa dijadikan alat pengintai sebagai efek pencegahan.

Pemeriksaan pajak merupakan proses pengumpulan dan pengevaluasian bahan bukti yang dilakukan oleh orang yang kompeten. Pemeriksaan pajak cenderung kepada audit ketaatan (compliance audit), karena salah satu tujuan dari pemeriksaan pajak adalah untuk menguji kepatuhan pemenuhan kewajiban perpajakan (Kurniawan, 2011). Untuk menguji kepatuhan wajib pajak dalam memenuhi kewajiban perpajakannya, maka Direktur Jenderal Pajak dapat melakukan pemeriksaan terhadap Wajib Pajak. Dari pelaksanaan pemeriksaan tersebut diharapkan adanya peningkatan kepatuhan tidak hanya dari Wajib Pajak yang diperiksa, melainkan dapat meluas yaitu dari Wajib Pajak lainnya (deterrent effect) maupun masyarakat yang belum terdaftar sebagai Wajib Pajak (Gunadi, 2004). Direktorat Jenderal Pajak (DJP) telah menetapkan peraturan tentang standar pemeriksaan yang digunakan untuk mengukur kualitas pemeriksaan yaitu capaian minimum yang harus dicapai dalam melaksanakan pemeriksaan.

Pemeriksaan pajak diperioritaskan kepada wajib pajak yang beresiko penghindaran pajak. Penegakan hukum (law enforcement) dibutuhkan untuk mencegah hilangnya penerimaan negara dari segi pajak. Wujud dari penegakan hukum melalui pelaksanaan fungsi pengawasan dan fungsi pemeriksaan yang dilakukan oleh pegawai Direktorat Jenderal Pajak berdasarkan peraturan berlaku. Namun, dalam praktiknya kegiatan penegakan hukum masih sangat rendah.

Mencapai target penerimaan bukan sesuai yang mudah, banyak sekali faktor yang mempengaruhi secara internal maupun eksternal dalam menghimpun penerimaan pajak. Sistem self assessmentyang diterapkan di Indonesia tentunya mewajibkan setiap Wajib untuk menghitung, menyetor dan melaporkan kewajiban perpajakannya sesuai kondisi yang sebenarnya dan DJP sebagai otoritas perpajakan mempunyai tugas melayani, menyuluh, mengawasi dan melakukan pemeriksaan sebagai upaya penegakan hukum kepada Wajib Pajak apabila kewajiban perpajakan tidak dilaksanakan sesuai kondisi yang sebenarnya.

Penelitian yang dilakukan Gunarso menunjukkan bahwa pemeriksaan pajak dan sanksi perpajakan berpengaruh terhadap perilaku patuh Wajib Pajak (Gunarso, 2016). Namun demikian, kepatuhan ini belum secara langsung berdampak kepada kenaikan 
penerimaan pajak, karena sebagian besar surat ketetapan pajak sebagai hasil pemeriksaan diajukan upaya hukum keberatan dan banding oleh Wajib pajak. Pemeriksan pajak tidak efektif dalam meningkatkan penerimaan pajak. Penelitian ini difokuskan pada jumlah penerbitan Surat Perintan Pemeriksaan (SP2) dengan jumlah surat ketetapan pajak yang diterbitkan ternyata tidak mampu mencapai target penerimaan.

Pada 11 September 2019, Direktorat Jenderal Pajak telah mengeluarkan SE24/PJ/2019 mengenai Implementasi Compliance Risk Management (CRM), dimana salah satu nya mengatur mengenai kegiatan pengawasan dan pemeriksaan pajak. Peraturan tersebut sebagai pengganti SE-40/PJ/2012 tentang Benchmark Behavioral Model. Compliance Risk Management itu merupakan suatu pengelolaan yang sistematis terhadap risiko kepatuhan yang ditimbulkan dari Wajib Pajak. Dalam Surat Edaran tersebut, CRM memfokuskan pada risiko dasar yang memengaruhi kepatuhan dalam pemenuhan kewajiban perpajakan WP. Risiko kepatuhan mencakup risiko dalam proses pendaftaran (registration), pelaporan (filling), dan pembayaran pajak (payment).

Menurut OECD (2004), Pengertian Compliance Risk Management "is a systemic approach to managing taxpayer compliance, advocating that risk treatments should vary according to risk severity and nature of the underlying behaviors, and should be designed to influence both current and future behaviors". Selain OECD, Pengertian Compliance Risk Management juga dijelaskan dalam European Commission (EC) (2010) " a systematic process in which a tax administration makes deliberate choices on which treatment instruments could be used to effectively stimulate compliance and prevent non-compliance, based on the knowledge of all (taxpayers' behaviour) and related to the available capacity".

Dari pengertian itu CRM merupakan suatu metode pengelolaan kepatuhan yang terdapat risiko dan perilaku wajib pajak. CRM itu bukan hanya mengenai pemeriksaan tetapi pendekatan yang komprehensif dalam mengelolah kepatuhan untuk meningkatkan penerimaan pajak. CRM juga merupakan suatu proses yang sistematis dalam administrasi pajak yang dapat digunakan secara efektif dalam kepatuhan maupun ketidakpatuhan pajak berdasarkan pengetahuan dari Wajib Pajak.

Direktorat Jenderal Pajak dalam mencapai target penerimaan pajak didukung melalui unit pelayanan dibidang perpajakan disebut Kantor Pelayanan Pajak (KPP). Salah satu tantangan yang dihadapi oleh KPP adalah tidak tercapainya penerimaan pajak pada tiap tahunnya. Biasanya, tidak tercapainya diakibatnya wajib pajak orang pribadi maupun wajib pajak badan yang melaporkan SPT Tahunan nya tidak secara sukarela melaporkan utang pajaknya secara keseluruhan, melakukan tindak penggelapan pajak dan tindak penghindaran pajak. Risiko yang dihadapi oleh AR menjadi beban yang ditanggung untuk dilakukan pemeriksaaan pajak. Pada tahun 2013-2019, KPP Pratama Senen tidak mencapai target penerimaan pajak, padahal terdapat empat KPP Pratama di Jakarta Pusat yang tercapai penerimaan pajak yaitu Pratama Gambir Satu, Pratama Sawah Besar Dua, Menteng Tiga, dan Tanah Abang Satu. Tidak tercapai nya target penerimaan menyebabkan kehilangan pajak. 
Atas dasar tersebut, peneliti melakukan penelitian mengenai penerapan Compliance Risk Management dalam rangka meningkatkan penerimaan pajak. Tujuan dari penelitian ini adalah untuk menganalisis penerapan dan evaluasi pemeriksaan pajak dengan Compliance Risk Management dalam meningkatkan penerimaan pajak pada KPP Pratama Senen. Penelitian ini Mengacu pada penelitian sebelumnya yaitu penelitian pertama yang dilakukan oleh (Arifanda Purba, 2012) menjelaskan dari hasil pemeriksaan di KPP Pratama Palmerah terdapat pola wajib pajak badan yang sektor usaha berpotensial yang dalam bidang usaha. Penelitian kedua yang dilakukan oleh (Muhammad Iqbal, 2013) menjelaskan pelaksanaan pemeriksaan pajak dengan metode Benchmark Behavioral Model ini terdapat beberapa kelemahan dari segi pelaksanaan, dan pengawasan sehingga kurang bisa dimanfaatkan dengan optimal pada setiap KPP. Penelitian ketiga dilakukan oleh (Muhammad Febran Nurdin, 2017) menjelaskan Penggunaan metode Benchamrk Behavioral Model tidak berjalan efektif dalam mengindentifiksai risiko kepatuhan di KPP dilingkungan Kanwil DJP Jakarta Selatan II dan pemilihan Benford's Law dalam mendeteksi ketidakpatuhan dapat digunakan secara mandiri di masing-masing. Fokus utama dalam penelitian ini adalah pemeriksaan pajak dengan model Compliance Risk Management, sehingga penelitian ini akan memberikan hasil yang belum pernah ditemukan sebelumnya. Model Compliance Risk Management ini sebagai kebaharuan dari Benchamrk Behavioral Model.

\section{Metode Penelitian}

(Hamidi (2007) menjelaskan mengenai Metode Peneletian yaitu suatu perangkat yang disusun secara sistematis, logis dan rasioanal. Biasanya, digunakan oleh peneliti dalam membuat perencanaan, mengumpulkan, menganalisis dan menghasilkan suatu kesimpulan.Pendekatan penelitian yang mendukung dalam penyusunan adalah pendekatan kualitatif. menyatakan:

"Qualitative approach is one in which the inquirer ofter makes knowledge claims based primarily on constructivist persperctives (i.e., the multiple enings of individual experiences meanings socially and historically constructed, with an intent of developing a theoryor pattern) or advocacy/participatory perspective (i.e., political, issue-oriented, collaborative, or change oriented) or both."

Dari definisi tersebut dapat dijelaskan pendekatan kualitatif itu suatu proses penelitian ilmiah berdasarkan masalah-masalah sosial yang digambarkan secara holistik dengan didukung informasi dari para informan. Infomasi yang diperoleh bisa berupa data berbentuk gambar, angka dan kata-kata.

Dalam penyusunan penelitian dilakukan secara deskriptif yaitu adanya data yang menggambarkan secara detail mengenai fenomena yang terjadi. Hal tersebut sesuai dengan pernyataan (Neuman, 2000:30) penelitian deskriptif adalah"

"Descriptive research presents pictures of specific details of situation, social setting, or relationship. The outcome of descriptive study is a detailed picture of the subject." 
Penelitian ini merupakan penelitian deskriftif kualitaif yang bertujuan untuk menggambarkan, meringkas berbagai kondisi, situasi, atau berbagai fenomena realitas sosial yang terjadi di masyarakat khususnya dalam melaksanakan pemeriksaan pajak ( Burhan Bungin, 2011).

Pemilihan pendekatan yang akan digunakan akan memberikan pemahaman secara mendalam terhadap penerapan model Compliance Risk Management sebagai pembaharuan dari Benchmark Behavioral Model di KPP Senen .

\section{Hasil dan Pembahasan}

\section{A. Analisis Penerapan Pemeriksaan Pajak dengan Model compliance Risk Management di KPP Pratama Senen}

Direktorat Jenderal Pajak (DJP) akhirnya menerapkan pengawasan kepatuhan berbasis risiko atau compliance risk management (CRM). Penerapan CRM merupakan bagian dari program reformasi perpajakan. Program ini merupakan kelanjutan dari amnesti pajak dan transparansi informasi keuangan. Tujuannya, untuk membangun profil risiko wajib pajak secara lebih canggih dan akurat. Sebelum, adanya CRM yang diberlakukan adalah Benchmark Behavioral Model (BBM), dimana alat bantu ini digunakan dalam mengindentifikasi risiko ketidakpatuhan yang dilakukan oleh wajib pajak badan. Hasil dari metode BBM ini adalah daftar prioritas wajib pajak yang perlu didalami kewajaran dalam penyampaian SPT.

Sebelum dikeluarkan kebijakan melalui SE-24/PJ/2019 ini, Dirjen Jenderal Pajak (DJP) mengadaptasi metode ini dari International Best Practice dan melalui Knowladge Sharing administrasi dari negara lain serta forum pengembangan Compliance Risk Management. Sebelumnya berbagai metode dan alat telah diciptakan oleh DJP untuk meningkatkan kepatuhan wajib pajak dengan menginstruksikan instansi vertikal dibawahnya agar lebih terukur secara kualitatif dan kuantitatif dalam metode pengawasan terhadap wajib pajak. Metode dan alat yang diciptakan oleh DJP selama ini masih terfokus kepada pemeriksaan dengan menggunakan rasio keuangan dengan pemetaan wilayah wajib pajak sebagai pembedanya. Oleh karena itu dikembangkan suatu metode identifikasi dan pengawasan terhadap kegiatan usaha wajib pajak yang dimulai Compliance Risk Management.

Penerapan analisis risiko dalam pengawasan terhadap wajib pajak berisiko mutlak dilakukan. Pada tahap identifikasi wajib pajak perlu ada mekanisme yang dapat memetakan Wajib pajak berdasarkan tingkat risikonya. Hal ini terkait dengan jumlah Wajib pajak yang sangat besar tetapi dengan terbatasnya jumlah pegawai yang mengawasi langsung Wajib pajak yaitu Account Representative. Dengan adanya model Compliance Risk Management ini DJP memiliki acuan untuk mengidentifikasi Wajib pajak Badan mana saja yang kepatuhan membayar pajaknya relatif rendah atau diluar kelaziman (undertax). Melalui model ini, diharapkan dapat 
membantu kerja dari Account Representative dalam melihat dan mengawasi Wajib pajak badan berisiko untuk selanjutnya ditindaklanjuti dengan strategi yang tepat.

KPP Pratama Senen telah menerapkan model Compliance Risk Management selama 1 tahun sejak diberlakukan pada tahun 2019. Model ini disediakan oleh Direktorat Jenderal Pajak melalui sistem basis data. Sistem ini sudah diberlakukan ke seluruh KPP di Indonesia. DJP telah melakukan sosialiasi mengenai model Compliance Risk Management agar kepatuhan wajib pajak meningkat yang secara langsung akan berdampak pada penerimaan pajak di setiap KPP di Indonesia.

Sejak penggunaan model Compliance Risk Management ini, KPP Pratama Senen pada tahun 2020 telah mencapai target penerimaan pajak sebesar 1.599.611.317.526 atau capaian 118,50 \%. Padahal pada tahun 2013-2019, realisasi penerimaan pajak yang dihimpun oleh KPP Pratama Senen tidak tercapai atau ratarata capaian hanya $80 \%$ dari target penerimaan pajak. Namun, dari tercapainya masih terdapat masalah yaitu hasil penerimaan CRM hanya berkontribusi $30 \%$ dari total kenaikan realisasi penerimaan pajak tahun 2020 dikurangi realisasi penerimaan pajak 2019 . Angka $30 \%$ dari kontribusi tersebut terlihat rendah mengingat CRM ini hanya sebagai alat bantu yang digunakan oleh pihak AR dalam meningkatkan penerimaan pajak.

Realisasi penerimaan pajak yang telah mencapai target penerimaan pada tahun 2020, hal tersebut dipengaruhi kepatuhan dari wajib pajak yang meningkat. Peningkatan kepatuhan itu dijelaskan dari rasio kepatuhan WPOP menjadi $101 \%$ apabila dibandingkan pada tahun 2019 hanya 84\% dan rasio kepatuhan WP Badan menjadi 83\% dibandingkan pada tahun 2019 sebesar 70\%. Kenaikan rasio kepatuhan didukung dengan patuhnya wajib pajak dalam melaporkan SPT pada KPP Pratama Senen. Penggunaan model Compliance Risk Management berhasil meningkatkan kepatuhan wajib pajak.

Tidak tercapainya penerimaan pajak pada 2019, AR melakukan penelitian awal dengan database yang disediakan oleh Direktorat Jenderal Pajak sebelum dilakukan pemeriksaaan pajak yaitu dalam matriks risiko ditemukan sebanyak 50 wajib pajak yang beresiko. Matriks risiko menjelaskan ketidakpatuhan tinggi dengan dampak fiskal yang tinggi ditunjukkan pada sumbu X3Y3 sebanyak 35 WP dan pada sumbu X3Y2 dengan dampak fiskal menengah sebanyak 1 WP. Ketidakpatuhan yang tinggi dibutuhkan pemeriksaan dan pengawasan secara berkelanjutan dari AR maupun Jabatan Fungsional. Berdasarkan hasil wawancara dari Tedhy sebagai AR, Wajib pajak yang telah selesai dilakukan pemeriksaan berdasarkan CRM sebanyak 19 Wajib Pajak. 


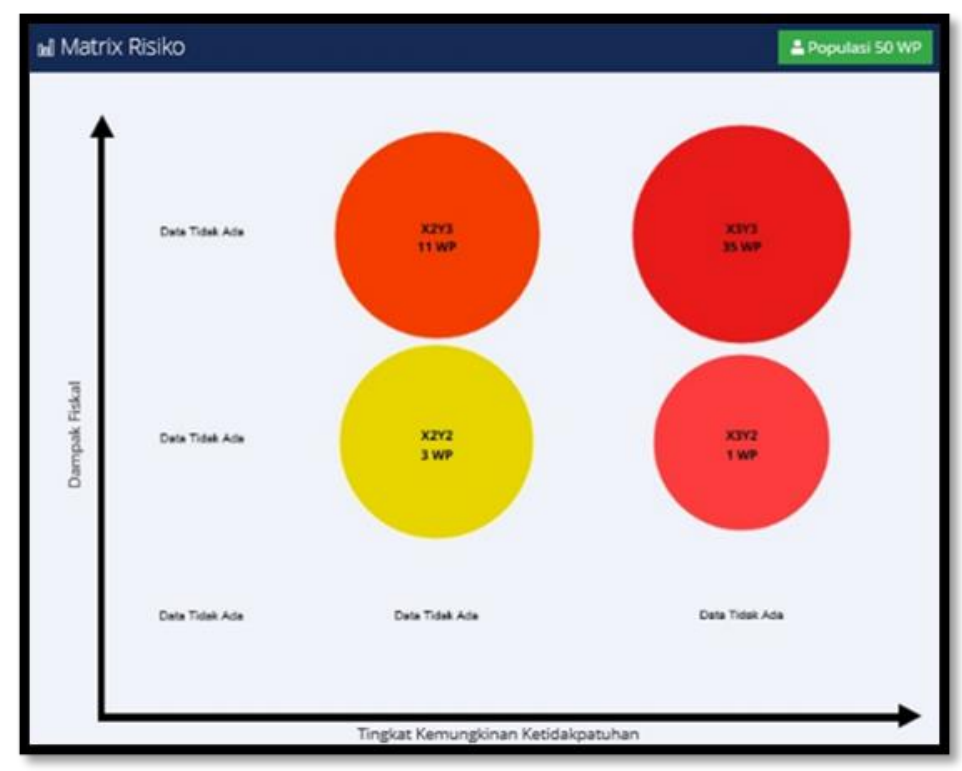

\section{Gambar 1 Matrik Risiko \\ Sumber: KPP Pratama Senen}

Proses Compliance Risk Management

\section{Identifikasi Risiko}

Proses identifikasi awal ini melalui hasil database CRM yang dikeluarkan oleh DJP. Database dipergunakan oleh AR untuk mengindentifikasi tingkat risiko. Setelah melakukan identifikasi awal, AR mengkelompokan wajib pajak berdasarkan tingkat risiko yang ditimbulkan. Berdasarkan matriks risiko menunjukkan terdapat 50 wajib pajak yang wajib dilakukan pemeriksaan karena memiliki rentang tingkat risiko dari menengah hingga tinggi. Matriks risiko didukung dengan hasil wawancara Kepala KPP Senen yaitu "Matriks risiko itu dipergunakan oleh AR untuk bukti penunjang untuk mengeluarkan SP2DK yang ditujukan kepada wajib pajak yang berpotensial".

\section{Penilaian Risiko}

Setelah melakukan identifikasi risiko, langkah selajantnya adalah Penilaian Risiko. Penilaian tersebut berdasarkan matriks risiko dari 50 wajib pajak yang wajib dilakukan pemeriksaan, terdapat tingkat risiko yaitu: X3Y3 itu memiliki risiko yang tinggi, X2Y2 itu memiliki risiko yang menengah dan X1Y1 itu risiko yang rendah. Risiko yang tinggi itu yang menjadi prioritas untuk dilakukan pemeriksaan pajak.

3. Analisis Risiko

Setelah dilakukan oleh penilaian risiko, AR bertugas melakukan menganalisis risiko berdasarkan hasil database CRM. Hasil analisis tersebut menunjukkan adanya ketidakpatuhan yang dilakukan oleh Wajib Pajak.Ketidakpatuhan yang tinggi disebabkan adanya risiko yang besar, namun wajib pajak tidak ingin melaksanakan kewajibannya.

Dalam penelitian ini, dari 50 wajib pajak harus dilakukan pemeriksaan hanya 6 wajib pajak PT yang dijadikan contoh wajib pajka berisiko. Contoh yang diambil dari Wajib Pajak PT. A ini terdapat nilai data kehilangan akibat ketidakpatuhan dari 
wajib pajak paling besar pada KPP Pratama Senen adalah -4,005,589,036 terkait ekualisasi biaya bunga. Lalu Ekualisasi Bukti Potong PPh 4 (2) Jasa Konstruksi terhadap Penghasilan Final SPT Tahunan sebesar -1,443,193,187. Wajib Pajak PT. A itu merupakan salah satu wajib pajak yang harus dilakukan dikarenakan terdapat risiko tinggi yang ditimbulkan. Level risiko pada WP A memiliki tingkat risiko sebesar 46,68 \% dari tingkat risiko tinggi secara Setelah memperoleh data risiko yang dimiliki oleh setiap wajib pajak, langkah selanjutnya yang dilakukan adalah menganalisis risiko tersebut lalu AR memberikan penyelesaian berdasarkan risiko tersebut.

4. Pemeriksaan dan Pengawasan

Dalam menetapkan wajib pajak yang berisiko, Direktorat Potensi, Kepatuhan, dan Penerimaan menyusun dan menyampaikan usulan daftar Wajib Pajak untuk setiap KPP Pratama melalui Nota Dinas Usulan Daftar Wajib Pajak. Lalu Kepala Bidang Data dan Pengawasan Potensi Perpajakan Kanwil DJP melakukan pembahasan dengan KPP mengenai usulan daftar Wajib Pajak Strategis dengan mempertimbangkan kriteria, jumlah, dan mekanisme penentuan Wajib Pajak berdasarkan nota dinas Direktur Potensi, Kepatuhan, dan Penerimaan. Lalu Kepala Kanwil DJP menetapkan Wajib Pajak untuk setiap KPP Pratama paling lama 10 (sepuluh) hari kerja setelah tanggal Nota Dinas.

Setelah dilakukan penetapan wajib pajak untuk setiap KPP Pratama oleh DJP. Langkah selanjutnya yang dilakukan oleh DJP adalah Assignment Wajib Pajak. Proses ini dilakukan oleh Kepala KPP Pratama dengan menerbitkan nota dinas tentang Assignment Wajib Pajak Strategis pada Seksi Pengawasan dan Konsultasi II. Lalu Kepala KPP Pratama menugaskan Kepala Seksi Pengolahan Data dan Informasi untuk memproses Assignment Wajib Pajak dalam Sistem lnformasi Direktorat Jenderal Pajak dengan jangka waktu paling lama 7 (tujuh) hari kerja sejak tanggal Surat Keputusan Penetapan Wajib Pajak.

Setelah dilakukan assignment, KPP Pratama akan melakukan penelitian terkait wajib pajak yang berisiko. Penelitian untuk Tahun Pajak berjalan dapat dilakukan untuk satu atau beberapa jenis pajak berdasarkan data dan/atau informasi yang dimiliki dan/atau diperoleh DJP sesuai dengan SE-39/2015,SE-49/20 dan/atau SE14/2018. Penelitian Untuk Tahun Pajak Sebelum Tahun Pajak Berjalan,dilakukan dengan langkah-langkah sebagai berikut:

1. Berdasarkan OPP, Kepala KPP Pratama menerbitkan Nota Dinas Penugasan kepada Supervisor untuk melakukan kegiatan penelitian, permintaan penjelasan atas data dan/atau keterangan, dan/atau konseling kepada Wajib Pajak Strategis, kecuali terhadap Wajib Pajak lnstansi Pemerintah, Wajib Pajak Kerja Sama Operasi (Joint Operation), Wajib Pajak PPJK dan Wajib Pajak cabang tanpa pusat.

2. Berdasarkan Nota Dinas, Supervisor sesuai dengan pengetahuan dan pengalaman yang dimilikinya bersama dengan Kepala Seksi Pengawasan dan Konsultasi dan Account Representative melakukan penelitian, permintaan 
penjelasan atas data dan/atau keterangan, dan/atau konseling kepada Wajib Pajak.

Hasil penelitian dituangkan dalam LHPt yang ditandatangani oleh Kepala KPP Pratama, Supervisor, Kepala Seksi Pengawasan dan Konsultasi, dan Account Representative. LHPt berisi kesimpulan hasil penelitian berupa Wajib Pajak telah atau belum memenuhi kewajiban perpajakan sesuai dengan ketentuan perpajakan sehingga Wajib Pajak diusulkan untuk dilakukan permintaan penjelasan atas data dan/atau keterangan. LHPt yang dilengkapi dengan KKPt dibuat dalam aplikasi Approweb,

Dalam hal setelah penetapan Wajib Pajak telah masuk dalam DSPP, maka terhadap Wajib Pajak yang belum diterbitkan NP2 untuk suatu Tahun Pajak, tetapi dilakukan penelitian dan Wajib Pajak dimasukkan dalam OPP sesuai dengan SE24/2019 atau terhadap Wajib Pajak yang telah diterbitkan NP2 untuk suatu Tahun Pajak maka proses pemeriksaan tetap dilanjutkan tanpa penelitian. Tindak Lanjut atas Hasil Penelitian Wajib Pajak pada KPP Pratama untuk Tahun Pajak Berjalan berdasarkan hasil penelitian dilakukan tindak lanjut berupa penyampaian permintaan penjelasan atas data dan/atau keterangan kepada Wajib Pajak sesuai dengan SE39/2015, SE-49/2016, dan/atau SE-14/2018; dan penyampaian usulan pemeriksaan untuk Tahun Pajak berjalan dapat diajukan setelah berakhirnya batas waktu penyampaian SPT Tahunan PPh untuk Tahun Pajak telah dilakukan penelitian atas seluruh jenis pajak (all taxes). Untuk Tahun Pajak sebelum Tahun Pajak Berjalan berdasarkan hasil penelitian atas pemenuhan kewajiban seluruh jenis pajak (all taxes) untuk suatu Tahun Pajak dilakukan tindak lanjut seperti Penyampaian permintaan penjelasan atas datadan/atau keterangan kepada Wajib Pajak,sebagai berikut penerbitan 1 (satu) SP2DK, dalam hal diketahui Wajib Pajak belum memenuhi kewajiban perpajakan sesuai dengan ketentuan perpajakan, pembahasan dengan Wajib Pajak dan pembuatan Berita Acara Pelaksanakaan Permintaan Penjelasan atas Data dan/atau Keterangan. Berdasarkan SP2DK yang telah disampaikan kepada Wajib Pajak dan/atau tanggapan Wajib Pajak atas SP2DK yang telah disampaikan maka diterbitkan LHP2DK dalam jangka waktu 14 (empat belas) dibuat dalam aplikasi Approweb.

Dalam hal LHP2DK telah diterbitkan tetapi Wajib Pajak tidak menyampaikan dan membetulkan SPT dalam jangka waktu 14 hari ,maka Kepala KPP harus mengusulkan pemeriksaan atau memberikan tambahan waktu penyampaian/pembetulan SPT. Apabila dalam penelitian ditemukan data baru yang mengakibatkan jumlah pajak terutang menjadi lebih besar daripada hasil penelitian yang tercantum dalam SP2DK maka dapat diterbitkan SP2DK baru sepanjang terhadap Wajib Pajak tersebut belum diusulkan untuk dilakukan pemeriksaan.

Penyampaian usulan pemeriksaan dengan langkah-langkah sebagai berikut :

1. Komite Perencanaan Pemeriksaan Tingkat Kanwil DJP melakukan penelitian riwayat atau proses pemeriksaan bukti permulaan dan penyidikan tindak pidana 
di bidang perpajakan terhadap Wajib Pajak yang diusulkan pemeriksaan dalam DSPP.

2. Lalu Kepala Kanwil DJP, setelah melakukan pembahasan dengan Komite Perencanaan Pemeriksaan Tingkat Kanwil DJP, memberikan persetujuan terhadap usulan pemeriksaan dengan jangka waktu paling lama 14 (empat belas) hari kalender sejak usulan pemeriksaan diterima.

Dalam hal diusulkan sebagai Pemeriksaan Khusus untuk seluruh jenis pajak (all taxes), dilakukan langkah-langkah sebagai berikuti :

1. LHP2DK sebagai dokumen Analisis Risiko atau usulan pemeriksaan.

2. Lalu Kepala KPP Pratama menyusun daftar Wajib Pajak yang diusulkan untuk dilakukan pemeriksaan dan menetapkannya masuk dalam DSPP.

3. Lalu Kepala KPP Pratama mengirimkan DSPP Wajib Pajak untuk dilakukan pemeriksaan langsung kepada Direktur Pemeriksaan dan Penagihan secara periodik, yaitu setiap akhir bulan.

4. Lalu Komite Perencanaan PemeriksaanTingkat Pusat melakukan penelitian riwayat dan/atau proses pemeriksaan bukti permulaan terhadap Wajib Pajak yang diusulkan pemeriksaan dalam DSPP.

5. Lalu Direktur Pemeriksaan dan Penagihan menerbitkan instruksi pemeriksaan khusus untuk semua jenis pajak (all taxes), setelah dilakukan pembahasan bersama Komite Perencanaan Pemeriksaan Tingkat Pusat, paling lama akhir bulan berikutnya setelah usulan pemeriksaan diterima.

Kegiatan pengawasan dan pemeriksaan dilakukan berdasarkan segmentasi Wajib Pajak dibagi menjadi 2 yaitu :

1. Wajib Pajak Strategis, yang dilaksanakan melalui kegiatan penelitian secara komprehensif.

2. Wajib Pajak Lainnya, yang dilaksanakan berbasis kewilayahan, kecuali Wajib Pajak yang sudah masuk dalam segmentasi Wajib Pajak Strategis.

Pengawasan dan pemeriksaan Wajib Pajak Strategis dilakukan penelitian secara komprehensif sebagai berikut: penelitian untuk Tahun Pajak berjalan dilakukan oleh Kepala Seksi Pengawasan dan Konsultasi dan Account Representative terhadap kepatuhan pemenuhan kewajiban perpajakan atas satu atau beberapa jenis pajak dan penelitian untuk Tahun Pajak sebelum Tahun Pajak berjalan dilakukan oleh Kepala Seksi Pengawasan dan Konsultasi dan Account Representative bersama dengan Supervisor Fungsional Pemeriksa (Supervisor) terhadap kepatuhan pemenuhan kewajiban perpajakan atas seluruh jenis pajak (all taxes).

Pengawasan itu penting dilakukan sebagai monitoring dalam kepatuhan wajib pajak. Pengawasan terhadap Wajib Pajak lainnya itu difokuskan pada kontribusi penerimaan pajak yang besar. Pengawasan ini pada prinsipnya dilakukan dengan berbasis kewilayahan, maka pengawasan harus dilakukan secara lebih intensif. Pengawasan ini dapat dilakukan oleh Account Representative berdasarkan pertimbangan Kepala KPP. 
Dalam pelaksanaan pengawasan dan/atau pemeriksaan dapat dilakukan permintaan bantuan penilaian kepada Fungsional Penilai sesuai dengan SE-05/2020, antara lain:

1. Terdapat transaksi yang menjelaskan nilai hasil penilaian yang dilakukan oleh DJP dalam rangka pelaksanaan Undang-Undang Pengampunan Pajak, harga/nilai pasar wajar,dan/atau harga limit,

2. Terdapat data lain yang mengindikasikan ketidakwajaran nilai yang dilaporkan Wajib Pajak,

3. Terdapat objek Pajak Bumi dan Bangunan sektor perkebunan, pertambangan, perhutanan, dan sektor lainnya yang dibutuhkan penilaian lapangan.

Kriteria, jumlah, dan mekanisme penentuan Wajib Pajak Strategis pada KPP Pratama serta target penyelesaian LHPt diatur dengan Nota Dinas Direktur Potensi, Kepatuhan, dan Penerimaan. Wajib Pajak Strategis merupakan Wajib Pajak yang termasuk dalam DSP3 yang selanjutnya ditentukan prioritasnya untuk dilakukan penelitian secara komprehensif untuk menjadi OPP. OPP oleh Kepala KPP melalui Komite Kepatuhan Wajib Pajak sebagaimana diatur dalam SE-24/2019 berdasarkan risiko ketidakpatuhan Wajib Pajak Strategis, yang antara lain menggunakan Compliance Risk Management (CRM), data internal, dan data eksternal.

Dalam rangka menjamin efektivitas pelaksanaan kegiatan pengawasan dan pemeriksaan Wajib Pajak, Kepala KPP bertanggung jawab yaitu mengoordinasikan dan mengawasi pelaksanaan kegiatan pengawasan dan pemeriksaan Wajib Pajak serta tindak lanjutnya. Kefektivitas itu sebagai tanda keberhasilan model compliance Risk Management yang dilakukan dalam pengawasan dan pemeriksaan wajib pajak.

\section{B. Evaluasi Terhadap Penerapan Pemeriksaan Pajak Dengan Model compliance Risk Management (CRM) Dalam Meningkatkan Penerimaan Pajak}

Dalam membangun kepatuhan wajib pajak DJP menyediakan fasilitas memadai untuk setiap petugas pajak dengan CRM dan membuat standarisasi data. Hal ini merupakan modal utama berjalannya CRM agar manajemen data dapat dilakukan secara lebih efektif dan efisien. Selain dapat memperbaiki administrasi pajak, CRM juga mendukung intensifikasi, ekstensifikasi, pengembalian pajak, dan penagihan yang mengarah pada peningkatan kinerja pengumpulan pajak sambil menjaga perekonomian.

Dengan perlakuan yang tepat, moral pajak masyarakat bisa semakin meningkat. Sebab, tidak semua wajib pajak diberikan perlakuan yang sama. Selain mengarahkan pemeriksaan kepada wajib pajak yang tidak patuh, peningkatan penerimaan pajak menjadi tujuan akhir yang ingin dicapai. Untuk mengukur keberhasilan program atau kebijakan tersebut yang perlu dilakukan adalah mengevaluasi suatu program dengan kriteria. Mengenai kinerja kebijakan dalam 
menghasilkan informasi terdapat kriteria evaluasi menurut William Dunn sebagai berikut:

1. Efektivitas

Pemahaman efektivitas itu berkenanan dengan apakah suatu alternatif mencapai hasil yang diharapkan. Hal yang ingin dituju adalah hasil tercapainya realisasi penerimaan pajak dan meningkatknya kepatuhan wajib pajak. Realisasi penerimaan pajak pada KPP Pratama Senen pada tahun 2020 tercapai sebesar 1.599.611.317.526 atau capaian nya $118,50 \%$. Realisasi penerimaan pajak yang tercapai itu dipengaruhi dengan meningkatnya rasio kepatuhan wajib pajak orang pribadi sebesar $17 \%$ dan rasio wajib badan sebesar $7 \%$ dalam melaporkan SPT pada KPP Pratama Senen. Hal tersebut menujukkan penerapan Compliance Risk Management efektif digunakan dalam mencapai target penerimaan pajak dan kepatuhan wajib pajak.

2. Efisiensi

Pemahaman efisiensi itu berkenaan dengan seberapa usaha yang diperlukan untuk mencapai hasil yang di inginkan. Pemahaman ini tidak terlepas dari adanya hubungan mengenai efektivitas. Tercapaimya penerimaan pajak pada tahun 2020 di KPP Pratama Senen ini dibantu alat bantu berupa Compliance Risk Management yang disediakan oleh Direktorat Jenderal Pajak. Penerapan CRM ini efisien karena tidak membutuhkan biaya yang besar. Hal itu dikarenakan dikelola secara nasional oleh Direktorat Jenderal Pajak dengan menggunakan data Tax Amnesty yang dilaporkan sukarela oleh wajib pajak pada tahun 2015 sebagai bahan dasar CRM tersebut, sehingga pihak KPP hanya perlu analisa dalam penentuan risiko kepada wajib pajak.

3. Perataan

Perataan pada penerapan pemeriksaan pajak Compliance Risk Management dengan tujuan meningkatkan penerimaan pajak dan kepatuhan wajib pajak yang dimaksud adalah ketentuan mengenai manfaat yang didistribusikan secara merata kepada stakeholder atau pemangku kepentingan. Stakeholder dalam penerapan Compliance Risk Management adalah wajib pajak dan pegawai jabatan fungsional.

Dari sisi wajib pajak perataan ini ditunjukan dengan meningkatnya kepatuhan dalam pelaporan SPT tahunan oleh wajib pajak orang pribadi dan wajib pajak badan. Dalam pemeriksaan pajak terdapat perbedaan wajib pajak dari tingkat risiko kepatuhannya melalui Peta Kepatuhan Wajib Pajak sesuai SE24/PJ/2019. Hal tersebut menegaskan bahwa regulasi tersebut secara merata sudah diterapkan. Regulasi tersebut didukung dengan adanya matriks risiko yang dikeluarkan oleh Direktorat Jenderal Pajak terdapat data 50 wajib pajak yang harus dilakukan pemeriksaan secara terperinci oleh AR karena memiliki risiko yang wajib diperiksa kembali dan sudah 37 wajib pajak yang telah selesai dilakukan pemeriksaan pajaknya. 
Selain, dari sisi wajib pajak perataan ini juga ditujukan kepada AR maupun Pemeriksa pelaksana. Pemberian tunjangan kinerja ini apabila KPP tersebut tercapai dalam penerimaan pajak pada tiap tahunnya berdasarkan Perpres No. 37 Tahun 2015 mengenai tunjangan kinerja pegawai di lingkungan Direktorat Jenderal Pajak. Tunjangan kinerja ini dibayarkan apabila $100 \%$ pada tahun berikutnya selama satu tahun dalam hal realisasi penerimaan pajak yang dihimpun sebesar 95\% atau lebih dari target penerimaan pajak. Pada KPP Pratama Senen pada tahun 2020 sudah tercapai 118,50\%, hal tersebut menjelaskan adanya pembayaran tunjangan kinerja sebesar $100 \%$.

4. Kecukupan

Pemahamaan mengenai kecukupan ini berkenaan sejauh mana hasil (output) dapat memecahkan masalah. Masalah yang dimaksud adalah tidak tercapainya penerimaan pajak dan kepatuhan wajib pajak. Asumsi nya bahwa penerapan pemeriksaan pajak dengan model Compliance Risk Management dapat dikatakan mencapai suatu kecukupan apabila hasil penerimaan pajak dapat memecahkan permasalahan tersebut.

Masalah yang dihadapi adalah tidak tercapainya penerimaan pajak pada KPP Pratama Senen pada tahun 2013-2019. Namun, masalah tersebut dapat diatasi dengan adanya output atau hasil yang memenuhi tingkat kecukupan setelah diberlakukan model Compliance Risk Management. Kenaikan penerimaan pajak yang cukup siginifikan sebesar $6 \%$ pada tahun 2019 yang semula sebesar $82 \%$ menjadi $118,50 \%$ pada tahun 2020 . Namun, dari tercapainya masih terdapat masalah yaitu hasil penerimaan CRM hanya berkontribusi $30 \%$ dari total kenaikan realisasi penerimaan pajak tahun 2020 dikurangi realisasi penerimaan pajak tahun 2019. Persentase $30 \%$ menunjukan belum cukup dalam meningkatkan penerimaan pajak.

Selain, masalah tidak tercapainya penerimaan pajak juga terdapat masalah dalam kepatuhan wajib pajak. Namun, masalah tersebut dapat diatasi dengan adanya output atau hasil yang memenuhi tingkat kecukupan setelah diberlakukan model Compliance Risk Management. Kenaikan rasio kepatuhan dari wajib pajak orang pribadi sebesar $17 \%$ dan wajib badan sebesar $7 \%$ dalam melaporkan SPT pada KPP Pratama Senen. Kenaikan rasio kepatuhan tersebut belum cukup dalam meningkatkan kepatuhan wajib pajak.

5. Responsivitas

Penerapan Compliance Risk Management sebagai alat bantu Direktorat Jenderal Pajak dalam melakukan pengawasan kepatuhan Wajib pajak Badan juga tidak lepas dari kendala dan permasalahan. Model ini dikeluarkan oleh DJP melalui Surat Edaran SE-24/PJ/2019 pada September 2019. Sampai dengan penelitian ini dilakukan, model CRM ini masih dalam penggunaan sepanjang tahun 2020 ini, dan hasil evaluasi dari Compliance Risk Management ini baru akan muncul di tahun 2021. Selama pelaksanaannya, terdapat respon dari masyarakat khusunya wajib pajak yaitu; 
a. Ketidakpatuhan pembayaran dan penyampaian SPT.

b. Wajib pajak belum pernah dilakukan pemeriksaan dengan ruang lingkup seluruh jenis pajak selama 3 tahun terakhir.

c. Analisis CTTOR, Gross Profit Margin (GPM), Nett Profit Margin (NPM) dibandingkan dengan hasil benchmarking industri sejenis di kanwil terkait. Risiko ketidakpatuhan dianggap tinggi apabila selisih antara analisis tersebut dengan rata-rata industri lebih besar dari $20 \%$.

d. Ketidaksesuaian antara profit SPT dengan profil ekonomi WP (usaha dan kekayaan) sesungguhnya berdasarkan fakta di lapangan.

e. Memiliki transaksi dengan pihak yang memiliki hubungan istimewa, berkedudukan di negara dengan tarif pajak lebih rendah dari Indonesia.

f.Memiliki transaksi afiliasi dalam negeri (intragroup transaction) dengan nilai transaksi lebih $50 \%$ dari total nilai transaksi.

g. Memiliki transaksi afiliasi dalam negeri dengan anggota grup usaha yang memiliki kompensasi kerugian.

h. Wajib pajak yang menerbitkan faktur pajak kepada pembeli dengan NPWP 000 lebih dari $25 \%$, dari total faktur pajak yang diterbitkan dalam satu masa pajak.

i. Terdapat hasil analisis IDLP dan/atau CTA untuk wajib pajak tersebut.

Selain respon dari wajib pajak yang dijelaskan diatas, terdapatnya kurangnya kesadaran dari wajib pajak dalam merespon dan menanggapi selama proses pemeriksaan pajak berlangsung. Selama dilakukan pemeriksaan, tidak semua wajib pajak secara sukarela melaporan pendapatan yang diperoleh. Hal tersebut menujukan adanya respon negatif dari wajib pajak yaitu pada tahun 2018, sebanyak 668 wajib pajak yang tidak menanggapi surat SP2DK, lalu pada tahun 2029 sebanyak 800 wajib pajak yang tidak menanggapi surat SP2DK dan pada tahun 2020 sebanyak 1083 yang tidak menanggapi.

6. Ketepatan

Pemahaman ketepatan ini dapat dipahami berkaitan dengan apakah hasil atau output yang diinginkan benar-benar tercapai atau bernilai. Penekanan berguna atau bernilai tersebut merupakan manfaat yang dirasakan oleh KPP Pratama Senen setelah diberlakukan penerapan Compliance Risk Management yaitu ketepatan dari hasil realisasi penerimaan pemeriksaan pajak dengan SP2DK dalam meningkatkan penerimaan pajak dan kepatuhan wajib pajak dalam melaporkan SP2DK. Pada tahun 2020, dari segi penerimaan pajak tercapai pada KPP Pratama Senen sebesar 1.599.611.317.526 atau capaian sebesar 118,50\%. Namun dari realisasi penerimaan SP2DK pada tahun 2020 sebesar 947.584.669.143 hanya memberikan kontribusi sebesar 59,2\%. Kontribusi sebesar 59,2\% belum tepat untuk meningkatkan penerimaan pajak.

Pada tahun 2020, dari segi rasio kepatuhan wajib pajak dalam melaporkan SP2DK sebesar 47\%. Namun dari rasio kepatuhan SP2DK hanya berkontribusi $50 \%$ dimana kontribusi belum tepat untuk meningkatkan kepatuhan wajib pajak karena masih terdapat wajib pajak tidak patuh dalam menanggapi laporan 
SP2DK. Penyampaian SP2DK pada tahun 2020 oleh wasakon II,III, dan IV sebanyak 2265 wajib pajak, namun yang memberikan tanggapan tertulis sebesar 697 wajib pajak, melakukan konseling sebesar 569 wajib pajak dan yang tidak menanggapi laporan SP2DK sebesar 1083 wajib pajak.

\section{Kesimpulan}

Penerapan Pemeriksaan Pajak dengan model Compliance Risk Management pada KPP Pratama Senen telah mencapai target dalam penerimaan pajak. Hal tersebut dapat ditunjukan bahwa realisasi penerimaan pajak pada tahun 2020 yang telah tercapai target sebesar Rp. 1.599.611.317.526 atau capaian 118,50 \% . Namun, dari tercapainya masih terdapat masalah yaitu hasil penerimaan CRM hanya berkontribusi $30 \%$ dimana kontribusi tersebut terlihat rendah mengingat CRM ini hanya sebagai alat bantu yang digunakan oleh pihak AR dalam meningkatkan penerimaan pajak. Realisasi penerimaan pajak yang tercapai itu dipengaruhi dengan meningkatnya rasio kepatuhan wajib pajak orang pribadi sebesar $17 \%$ dan rasio wajib badan sebesar $7 \%$ dalam melaporkan SPT pada KPP Pratama Senen. Sehingga penggunaan model Compliance Risk Management berhasil meningkatkan kepatuhan wajib pajak.

Evaluasi penerapan pemeriksaan pajak dengan model Compliance Risk Management pada KPP Pratama dalam penerimaan pajak Senen dengan enam kriteria evaluasi yaitu Efektivitas yaitu penerapan Compliance Risk Management ini efektif dalam hal tercapai penerimaan pajak dan meningkatkan kepatuhan wajib pajak, Efisiensi yaitu penerapan Compliance Risk Management ini efisien dalam pengeluaran biaya karena penggunaan database disediakan oleh Direktorat Jenderal Pajak berupa database Tax Amnesty pada tahun 2016 yang dijadikan bahan untuk dilakukan pemeriksaan pajak, Perataaan yaitu penerapan Compliance Risk Management ini dapat meningkatkan kepatuhan wajib pajak dan para stakeholder menerima pembayaran tunjangan kinerja sebesar $100 \%$ apabila hal realisasi penerimaan pajak yang dihimpun sebesar $95 \%$ atau lebih dari target penerimaan pajak, Kecukupan yaitu penerapan Compliance Risk Management belum cukup untuk meningkatkan realisasi penerimaan pajak dan kenaikan rasio kepatuhan tersebut belum cukup dalam meningkatkan kepatuhan wajib pajak pada KPP Pratama Senen, Responsivitas yaitu selama dilakukan pemeriksaan dengan Compliance Risk Management ini terdapat dari respon negatif dari wajib pajak yaitu adanya kurangnya kesadaran dan sukarela dalam melaporkan keseluruhan pendapatan yang diperoleh, Ketepatan yaitu hasil pemeriksaan pajak dengan SP2DK belum tepat dalam meningkatkan penerimaan pajak dan meningkatkan kepatuhan wajib pajak. Sehingga dapat dikatakan meningkatnya realiasasi penerimaan pajak tercapai dan meningkatkan kepatuhan wajib pajak bukan disebabkan model Compliance Risk Management. 


\section{BIBLIOGRAFI}

Birskyte, Liucija. (2008). The effects of IRS audit rates on state individual income tax compliance. Indiana University.

BunginH.M. Burhan, (2011), Penelitian Kualitatif, Edisi kedua. Jakarta:Prenada Media Group

European Commission (EC) (2010). Compliance Risk Management. Guide for Tax Administrations. Fiscalis Risk Management Platform Group.

Elim, Inggriani; Panga, Ricky Billy, (2015). Analisis Efektifitas Pemeriksaan Pajak dalam Upaya Meningkatkan Penerimaan Pajak pada Kantor Pelayanan Pajak Pratama Bitung. Universitas Sam Ratulangi

Gunadi, (2004). Bunga Rampai Pemeriksaan Penyidikan dan Penagihan Pajak. Jakarta: MUC Publishing

Gunarso, Pujo, (2016). Pemeriksaan Pajak dan Sanksi Pajak Terhadap Kepatuhan Wajib Pajak badan Pada KPP Kepajen Kabupaten Malang, Malang; Universitas Merdeka Malang.

Hamidi. 2004. Metode Penelitian Kualitatif: Aplikasi Praktis Pembuatan Proposal dan Laporan Penelitian. Malang: UMM Press.

Iqbal,Muhammad. (2013). Analisis Penerapan Metode Benchmark Behavioral Model dalam Pemeriksaan Pajak (Tinjauan Kritis terhadap SE-40/PJ/2012). Tesis FIA, Universitas Indonesia.

Kurniawan, Anang Mury, (2011). Upaya Hukum Terkait dengan Pemeriksaan, Penyidikan dan Penagihan Pajak. Yogyakarta: Graha Ilmu.

Leviner, Sagit. (2008). A new era of tax enforcement: From big stick to responsive regulation. U. Mich. JL Reform, 42, 381.

Mason, Mark. (2008). Complexity theory and the philosophy of education. Educational Philosophy and Theory, 40(1), 4-18.

Nurmantu, Safri. (2005). Pengantar Perpajakan. Edisi Ke-3. Jakarta: Granit.

Nurdin, Muhammad Febran. (2017). Analisis Benford's Law Model sebagai alternatif metode benchmark behavioral model dalam pengawasan kepatuhan wajib pajak (studi kasus: Kantor Wilayah DJP Jakarta Selatan II). Tesis FIA, Universitas Indonesia.

Purba, Arifanda. (2012). Analisis Hasil Pemeriksaan Pajak Tahun 2008-2011 Untuk Menentukan Pola Profil Wajib Badan yang Potensial di Kantor Pelayanan Pajak Pratama Palmerah. Tesis FIA,Universitas Indonesia. 
Analisis Penerapan Pemeriksaan Pajak dengan Model Compliance Risk Management (CRM) Dalam Meningkatkan Penerimaan Pajak pada KPP Pratama Senen

Organisation for Economic Co-operation and Development (OECD).(2004).

Compliance Risk Management: Managing and Improving Tax Compliance. Paris: OECD Forum on Tax Administration. 